Article

\title{
Eco-Friendly Synthesis and Antimicrobial Activity of Silver Nanoparticles Using Dracocephalum moldavica Seed Extract
}

\author{
Zahra Haghighi Pak ${ }^{1}$, Hossein Abbaspour ${ }^{1, *}$, Naser Karimi ${ }^{2, *}$ and Ali Fattahi ${ }^{3}$ \\ 1 Department of Biology, Damghan Branch, Islamic Azad University, Damghan 36716-39998, Iran; \\ z.haghighipak@gmail.com \\ 2 Laboratory of Plant Physiology, Department of Biology, Faculty of Science, Razi University, \\ Kermanshah 67149-67346, Iran \\ 3 Department of Pharmaceutics, School of Pharmacy, Kermanshah University of Medical Sciences, \\ Kermanshah 67346-67149, Iran; a.fatahi.a@gmail.com \\ * Correspondence: abbaspour75@yahoo.com (H.A.); nkarimi@razi.ac.ir (N.K.); Tel./Fax: +98-232-5235016 \\ (H.A.); +98-833-4274545 (N.K.)
}

Academic Editor: Philippe Lambin

Received: 13 October 2015; Accepted: 28 January 2016; Published: 2 March 2016

\begin{abstract}
This paper reports a novel green approach for the synthesis of silver nanoparticles (AgNPs) using aqueous seed extract of Dracocephalum moldavica (L.) under ambient conditions. Processes such as Ultraviolet-visible (UV-vis) spectrometer, field emission scanning electron microscopy (FESEM), $X$-ray diffraction (XRD), Fourier transform infrared spectroscopy (FTIR), energy dispersive X-ray analysis (EDX), and transmission electron microscopy (TEM) were carry out to characterize AgNPs. The presence of AgNPs in the prepared solution was approved by a peak to occur at $443 \mathrm{~nm}$. XRD pattern indicated the crystalline structure of the nanoparticles (NPs) while the FTIR spectra confirm the attendance of plant residues adsorbed by these NPs. TEM images revealed a near spherical shape of these NPs, and EDX provided the expected elemental composition. The synthesized AgNPs showed excellent antimicrobial activities against Escherichia coli, Pseudomonas aeruginosa, Staphylococcus aureus, Serratia marcescens, Staphylococcus epidermidis and Bacillus subtilis.
\end{abstract}

Keywords: nano silver; Dracocephalum moldavica; XRD; FTIR; antibacterial activity

\section{Introduction}

The synthesis of nanoparticles (NPs) has become a matter of great interest due to their different beneficial properties and applications in a variety of fields [1-3]. Several approaches have been proposed to generate metallic NPs, including electro-chemical, sonochemical, and photochemical processes; however, most of these methods suffer from the utilization of toxic, hazardous chemicals, and difficulty in purification [4-6].

Green chemistry synthesis of NPs has recently received wide spread attention among physical and chemical synthesis processes for its emergence as a simple, speedy synthesis, inexpensive, eco-friendly, and size-controlling approach in the synthesis of metal NPs (MNPs) [3]. As a result of its growing popularity, there is an increased need to produce MNPs using biological systems such as bacteria [7], fungi [8], yeast [9], and plant extracts $[3,10,11]$ as reducing and stabilizing agents. The latter synthetic procedure exemplifies a green approach. NPs produced by angiosperms, especially those medicinal in nature, are more stable, display a more speedy synthesis in the case of micro-organisms, reveal greater variation in shape and size and contain important reducing agents in comparison to those produced by other organisms $[12,13]$. 
Silver (Ag) has long been known to exhibit a strong antimicrobial, catalysis, and surface-enhanced Raman scattering; therefore, Ag-based compounds have been used extensively in numerous bactericidal applications [3,14]. Since antibiotic resistance to the microorganisms become more common, and a continued preoccupation with health care expenses, researchers have tried to develop new resistance-free, cost-effective antimicrobial reagents [3]. The antimicrobial potential of Ag-based NPs has led to their incorporation in consumer, health-related, and industrial products [3,15]. Moreover, due to its potential application to biological functions such as cancer therapy and imaging, AgNP biosynthesis has recently attracted considerable attention of researchers interested in the field $[11,14,15]$.

Although AgNP synthesis has already been reported in various plant seed extracts such as Medicago sativa [16], Artocarpus heterophyllus [17], Jatropha curcas [18], Strychnos potatorum [19], Foeniculum vulgare [20], Silybum marianum [21], and Syzygium cumini [22], the field continues to receive attention due to the variety and high prospective of plants for producing NPs with different characteristics [11]. Additionally, the plant-based extracts of antioxidant-laden leaves, seeds, fruits, roots, and stems have been considered for use in the synthesis of AgNPs [10,23].

Originating from south Siberia and the Himalayan mountains, dragonhead (Dracocephalum moldavica L.) is a perennial, herbaceous plant belonging to the Lamiaceae family [1,2]. Recent pharmacological studies have confirmed antioxidant, antiseptic, antibacterial, and carminative properties of the plant's essential oil [1], and the areal parts of D. moldavica are applied in traditional West Azerbaijani (Iranian) medicine for general diuretic, digestive, sedative, and antiemetic uses [2].

Terpenoids are believed to take part in the reduction of Ag ions and the stabilization of following NPs [6]; therefore, we used D. moldavica seed extract as a reducing and stabilizing agent in the synthesis of AgNPs, with the intention of exploring its medicinal properties. As there appears to be no report concerning the synthesis of NPs using D. moldavica seed extract to date, the present study was designed to phytosynthesize AgNPs using D. moldavica seed extract, and to subsequently investigate the antimicrobial activities of synthesized NPs.

\section{Materials and Methods}

\subsection{Collection of Seeds}

D. moldavica seeds were purchased from the Pakan Bazr Company in Isfahan, Iran. The seeds were first rinsed with water three times, and then cleansed with Milli-Q water to remove the fine dust particles, and finally air dried for 1 week to remove all moisture completely.

\subsection{Preparation of Aqueous D. Moldavica Seed Extract, and Synthesis of AgNPs}

Twenty grams of $D$. moldavica seeds were finely stirred with $200 \mathrm{~mL}$ of deionized water at $85^{\circ} \mathrm{C}$ for $15 \mathrm{~min}$ until no foreign material remained. The seed extract was then filtered through filter paper, and the filtrate was then kept at $4{ }^{\circ} \mathrm{C}$ for further experimentation regarding use of the extract as a reducing and stabilizing agent. Remaining extract must be used within three days of the filtration process.

The synthesis of AgNPs involved different applications of seed extracts which were dried and then optimized to $1 \mathrm{~mL}$. One milliliter of the extract was added to $100 \mathrm{~mL}$ of the previously concocted silver nitrate $\left(\mathrm{AgNO}_{3}\right)$ solution, shakes and exposed to sunlight irradiation conditions for the reducing $\mathrm{Ag}^{+}$to $\mathrm{Ag}^{0}$. The solution including AgNPs was centrifuged at 10,000 rpm for $15 \mathrm{~min}$, after which the re-dispersion of the pellet in the Milli-Q water to remove any unbound biological molecules. Purified pellets were then placed onto glass Petri dishes and incubated for $24 \mathrm{~h}$ at $60{ }^{\circ} \mathrm{C}$ for drying. The color change of $\mathrm{AgNO}_{3}$ solution turned from colorless to brown, indicating the creation of AgNPs. Dried AgNPs were scraped out for the further study [11].

\subsection{Characterization of Silver NPS}

Nanoparticles are generally characterized by their size, shape, surface area, and dispersity [24,25]. The usual techniques which used to characterizing NPs are as follow: Ultraviolet-visible spectroscopy, 
FSEM, TEM, FTIR and XRD [11]. For the purposes of this study, synthesized AgNPs were characterized using UV-visible spectroscopy. The biologically reduced brown color solution mixture was recorded as a function of the reaction time on a Shimadzu Lambda UV mini-1240 instrument (from 250 to $800 \mathrm{~nm}$ ) operating at a resolution of $1 \mathrm{~nm}$ [11]. The reaction mixture of seed extracts and AgNPs was subjected to centrifugation at $8000 \times \mathrm{g}$ for $15 \mathrm{~min}$, and, according to the aforementioned process, the resulting pellet was washed three times with deionized water and filtered. An aliquot of this filtrate was used for FTIR, XRD, FESEM and TEM analysis [26].

Detection of possible biomolecules absorbed on the synthesized AgNPs involved FTIR analysis, which was recorded by its scanning in the range $350-4000 \mathrm{~cm}^{-1}$ at a resolution of $4 \mathrm{~cm}^{-1}$ in potassium bromide pellets [13]. For XRD studies, synthesized AgNPs were coated on an XRD grid, and the spectra were recorded using an Italian APD $2000 \mathrm{X}$-ray generator operating at a voltage of $40 \mathrm{kV}$ and a current of $30 \mathrm{~mA}$ with $\mathrm{Cu} \mathrm{K} \mathrm{K}^{-1}$ radiation. The surface morphology and size distribution of AgNPs were characterized using JEOL JSM 6700F (FE-SEM) and Transmission Electron Microscopy (TEM) measurements from a TECHNA I10-Philphs instrument. The purity and elemental composition of the AgNPs were analyzed using a RONTEC EDX-spectroscopy system model Quan Tax 200, Germany.

\subsection{In-Vitro Antimicrobial Activity}

Antibacterial activity of AgNPs was assayed against different Gram-positive and Gram-negative pathogenic bacteria such as Escherichia coli, Pseudomonas aeruginosa, Staphylococcus aureus, Serratia marcescens, Staphylococcus epidermidis and Bacillus subtilis by using the agar well diffusion technique [27]. In this technique, bacterial cultures were inoculated on nutrient agar containing various contents of constituents. After solidification of the medium, cotton swabs were placed on the surface and holes were punch with the bacterial suspensions. Synthezied AgNPs were included into the wells created in the plates, and the D. moldavica seed extract was used as a control. The samples were incubated for $24 \mathrm{~h}$ at a $37^{\circ} \mathrm{C}$ temperature. If a zone of inhibition was observed around the well after the incubation period, then a positive result was concluded. Tests were performed in triplicate, and mean values of zone diameter were recorded.

A minimum inhibitory concentration (MIC) test was conducted with the synthesized AgNPs. Various concentrations of seed extract-synthesized AgNPs were prepared with dimethyl sulphoxide (DMSO) in roughly $0.5 \mathrm{~mL}$ increments, and subsequently mixed with $50 \mu \mathrm{L}$ of 24 h-old individual bacterial pathogens. Each mixture was incubated at $37^{\circ} \mathrm{C}$ for $48 \mathrm{~h}$, and the visible turbidity was observed in each concentration in order to calculate MIC [28].

\section{Results and Discussion}

Photochemicals from D. moldavica seed extract can be used as both reducing and capping agents to synthesize AgNPs. Figure 1 shows the D. moldavica seeds extract mixed with $\mathrm{Ag}^{+}$before and after microwave irradiation, respectively [3]. In this study, the colorless $\mathrm{AgNO}_{3}$ solution turned from yellow to brown or from pale yellow to black brown, indicating the formation of AgNPs, indicating the formation of $\mathrm{Ag}$ in the solution and excitation of surface plasmons [16].

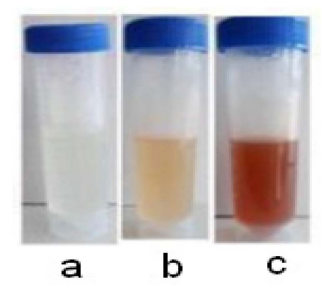

Figure 1. Photograph of colloids; (a) Dracocephalum moldavica (L.) seed extract; (b) silver nitrate solution; (c) silver nanoparticle. 
The formation of man-sized Ag can be confirmed by employing optical absorption spectroscopy. In the present study, the AgNP mixture was transferred in to a cuvette for UV-visible radiation, and the medium absorbance was recorded. Due to surface plasmon resonance (SPR) phenomena, resonant peak occurs at a variety of wavelengths for various NPs mixture and, according to the theory of resonance maximum wavelength, is absorbed at resonant wavelengths [6,24]. The previous studies suggest that a usual AgNP shows SPR patterns at wavelengths in the range of 400-480 nm. Figure 2 shows that SPR for the prepared mixture occurred at a wavelength of $443 \mathrm{~nm}$, confirming the presence of AgNPs. SPR pattern of metallic nanoparticles depend on the stabilizing molecule, shape and size of particles present in the medium or upon inner particle distance and surrounding media $[24,29,30]$.

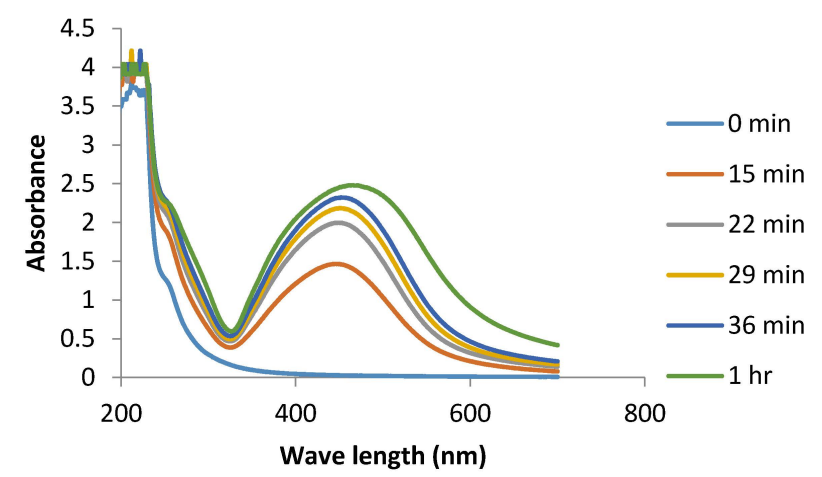

Figure 2. UV-Visible absorption spectrum of silver nanoparticles (AgNPs) solution observed at $\sim 450 \mathrm{~nm}$ as a function of Irradiation time.

Figure 3 presents an absorbance vs. $2 \theta$ graph depicting XRD patterns of synthesized AgNPs. Three diffraction peaks as (111), (200), (220), and (311) were observed in the $2 \mathrm{~h}$ range of 30-80, indicated expressions of face centered cubic ( $\mathrm{fcc}$ ) structure metallic $\mathrm{Ag}$, respectively. These observations reveal that synthesized AgNPs consist of pure crystalline Ag [3,31,32]. Similar XRD pattern reports were observed in the Eclipta prostrate, Tribulus terrestris, and Prosopis juliflora extracts for synthesized AgNPs [13,30,33-38].

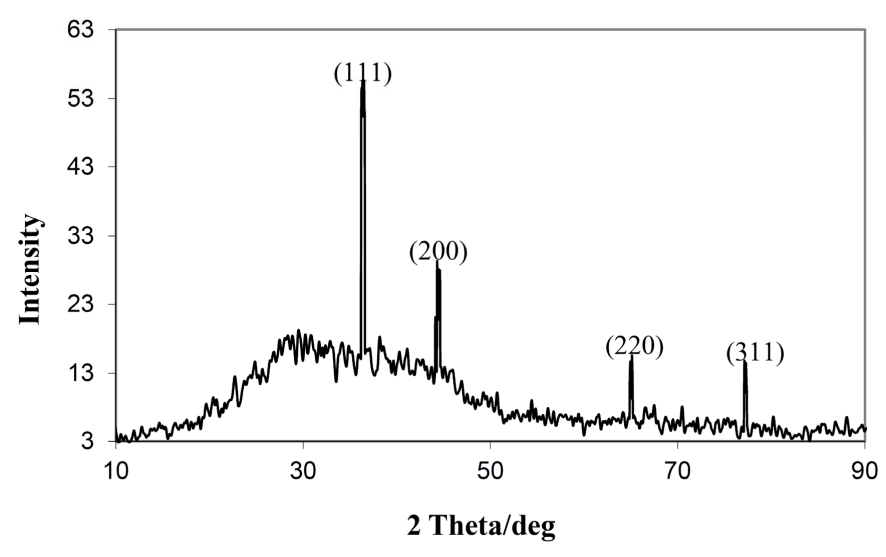

Figure 3. X-ray diffraction (XRD) patterns of synthesized AgNPs.

FTIR analysis was used to identify and characterize probable biomolecules responsible for the reduction and capping of AgNPs achieved from the D. moldavica seed extract [3]. The biologically synthesized AgNPs and the powdered seeds were mixed with the potassium bromide to make a pellet. Figure 4 shows the FTIR spectra of pre-reaction dried D. moldavica seed extract without $\mathrm{AgNO}_{3}$ (control), and the synthesized post-reaction AgNPs, with $\mathrm{AgNO}_{3}$. 
Both FTIR spectra show a shift in peaks: 1401-1396 (due to C-C in-ring stretching of aromatic amines), 1650-1616 (due to $-\mathrm{C}=\mathrm{C}-$ stretching of alkenes, and $\mathrm{N}-\mathrm{H}$ bend of primary amines), 2928-2912 (corresponding to $\mathrm{C}-\mathrm{H}$ stretching of alkanes, and $\mathrm{O}-\mathrm{H}$ stretching of carboxylic acids), and $3352-3386 \mathrm{~cm}^{-1}$ (due to $\mathrm{N}-\mathrm{H}$ stretching of amines and amides, $\mathrm{O}-\mathrm{H}$ stretching of alcohols and phenols). In addition, synthesized AgNPs showed strong band, specifically at a peak of $1067 \mathrm{~cm}^{-1}$, related to aliphatic amines (C-N stretching vibration). In brief, FTIR analysis results showed the presence of alcohols, amides, alkanes, carboxyl, and phenols in synthesized AgNPs. A similar trend is observed in the synthesis of AgNPs using Artocarpus heterophyllus Lam. [39] and Abelmoschus esculentus [33] seed extracts.

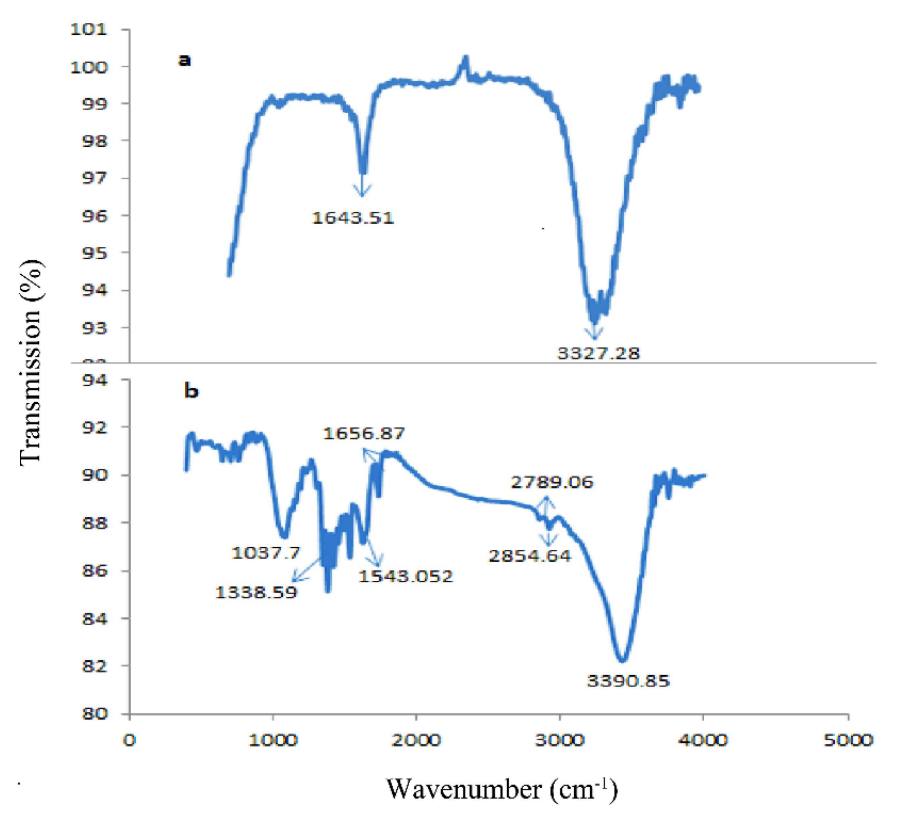

Figure 4. Fourier transform infrared (FTIR) spectra of Dracocephalum moldavica powder before (a) and after $(\mathbf{b})$ reaction.

The size and morphology of synthesized AgNPs were determined by TEM images, as shown in Figure 5. The morphology of AgNPs is almost spherical, and newly formed NPs exhibited high surface areas, an average size of $31 \pm 6 \mathrm{~nm}$ in the range of $5-50 \mathrm{~nm}$, and monodispersity in terms of particle size. Figure 6 shows the FESEM images and EDX spectra of AgNPs. FSEM micrographs in Figure 6A reveal that aggregates of AgNPs are not indirect contact, indicating stabilization by capping agents. Of medicinal importance, biocapped molecules help to prevent agglomeration of NPs and also enhance antimicrobial activity.

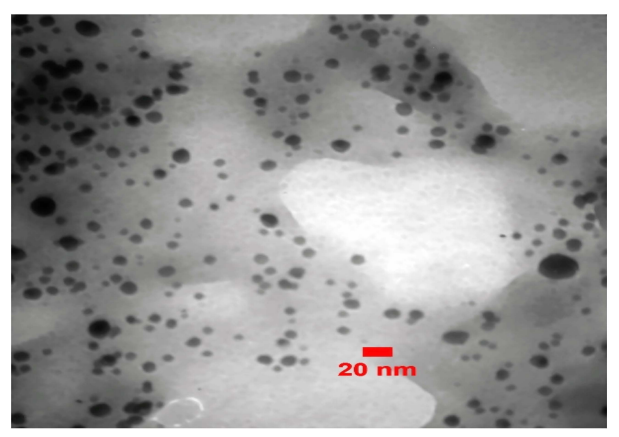

Figure 5. Transmission electron microscopy (TEM) micrograph of AgNPs synthesized from seed aqueous extract $N$. arvensis with different magnification. 
EDX spectra confirmed that Ag is only the major element present in the NPs under study. The insignificant amounts of observed $\mathrm{C}$ and $\mathrm{O}$ are attributed to the plant biomass attached to the NPs (Figure 6B). Yallapa et al. reported similar results in previous reports for AgNPs by using A. farnesiana plant extracts [37], and Song and Kim and Raghunadan et al. discovered C and O in MNPs obtained using pine, persimmon, magnolia, ginkgo, platanus, and guava extracts $[3,40,41]$.

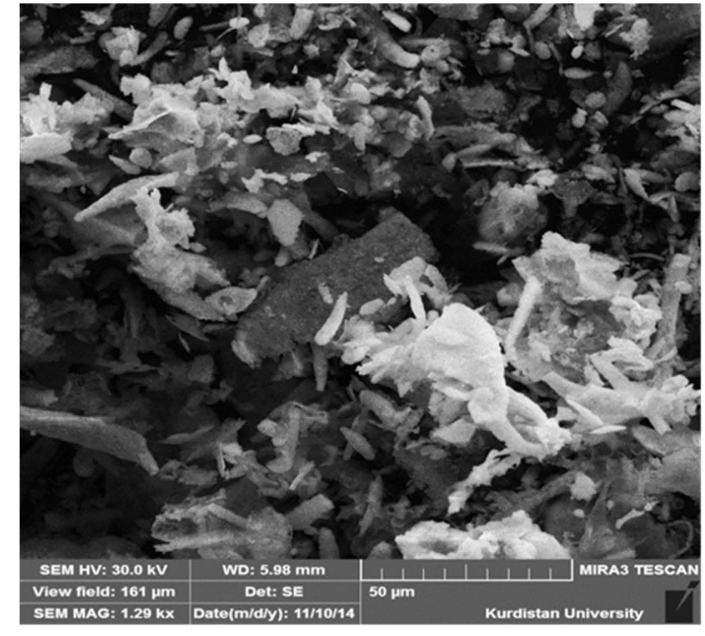

(A)

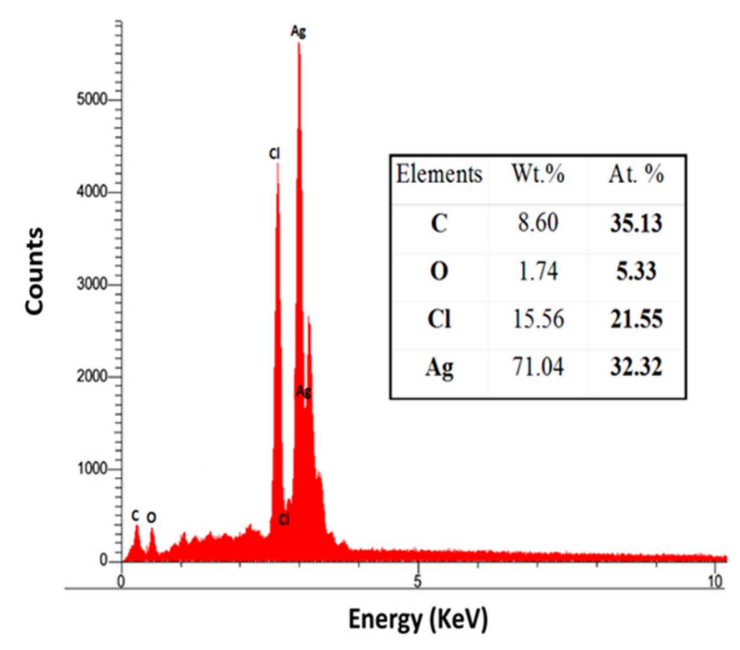

(B)

Figure 6. (A) FSEM images and (B) EDAX results indicating the synthesis of silver NPs and bioactive components of Dracocephalum moldavica.

The antimicrobial and antibiotics resistance of human pathogens made as problematic issue which needs to discover new natural alternates to overcome this problem $[42,43]$. The antibacterial activity of synthesized AgNPs was tested against six bacteria: S. aureus, S. epidermidis, B. subtilis as Gram positive bacteria, E. coli, P. aeruginosa, and S. marcescens as Gram negative bacteria. The results are presented in Table 1 as the average values of zone of inhibition radii and MIC. Disc diffusion test results indicate that the maximum zone of inhibition against $S$. marcescens is $19.5 \mathrm{~mm}$, while E. coli requires $17.6 \mathrm{~mm}$ and the remaining four bacteria were only fairly susceptible (Table 1). These results support the findings of Ingle et al. [44], which suggest that AgNPs exhibit significant antimicrobial activity against $E$. coli and multidrug-resistant bacteria.

Table 1 shows the MIC values of AgNPs for different bacteria. S. marcescens $(8 \mu \mathrm{g} / \mathrm{mL})$ was observed as the most sensitive bacteria, followed by E. coli $(11 \mu \mathrm{g} / \mathrm{mL})$, B. subtilis $(22 \mu \mathrm{g} / \mathrm{mL})$, P. aeruginosa $(12 \mu \mathrm{g} / \mathrm{mL})$ and S. epidermidis $(25 \mu \mathrm{g} / \mathrm{mL})$. S. aureus $(25 \mu \mathrm{g} / \mathrm{mL})$ exhibited the highest MIC value, and, as revealed by the same graphic, an evident MIC value trend is associated with Gram negative and Gram positive bacteria. E. coli as Gram negative bacterium showed a maximum zone of inhibition of $13 \mathrm{~mm}$, due in part to the presence of a peptidoglycan layer in Gram positive bacteria. In the presence of this layer, bacteria form a more inflexible construction, leading to difficulty in penetration by AgNPs. Conversely, Gram negative bacteria encounter a cell wall with a thinner peptidoglycan layer, facilitating AgNP penetration [45,46]. 
Table 1. Antibacterial activity of biosynthesized silver nanoparticles using D. moldavica seed extract.

\begin{tabular}{|c|c|c|c|c|c|c|}
\hline \multirow[t]{2}{*}{ Pathogens } & \multicolumn{2}{|c|}{$\begin{array}{l}\text { D. moldavica } \\
\text { Seed Extract }\end{array}$} & \multicolumn{2}{|c|}{$\begin{array}{l}\text { Synthesized Silver } \\
\text { Nanoparticle }\end{array}$} & \multicolumn{2}{|c|}{$\mathrm{AgNO}_{3}$} \\
\hline & $\begin{array}{c}\text { Disk } \\
\text { Diffusion } \\
\text { Assay } \\
(\mathrm{mm} \cdot \text { dia) }\end{array}$ & $\begin{array}{l}\text { MIC } \\
\left(\mu \mathrm{g} \cdot \mathrm{mL}^{-1}\right)\end{array}$ & $\begin{array}{c}\text { Disk } \\
\text { Diffusion } \\
\text { Assay } \\
(\mathrm{mm} \cdot \text { dia })\end{array}$ & $\begin{array}{c}\text { MIC } \\
\left(\mu \mathrm{g} \cdot \mathrm{mL}^{-1}\right)\end{array}$ & $\begin{array}{c}\text { Disk } \\
\text { Diffusion } \\
\text { Assay } \\
(\mathrm{mm} \cdot \text { dia })\end{array}$ & $\begin{array}{c}\text { MIC } \\
\left(\mu \mathrm{g} \cdot \mathrm{mL}^{-1}\right)\end{array}$ \\
\hline Staphylococcus aureus & - & - & $8.4 \pm 0.76$ & $29.6 \pm 0.00$ & $11.6 \pm 0.88$ & $16 \pm 0.00$ \\
\hline Staphylococcus epidermidis & - & - & $11 \pm 1.66$ & $25 \pm 0.00$ & $9 \pm 0.43$ & $25 \pm 0.00$ \\
\hline Bacillus subtilis & - & - & $10 \pm 0.77$ & $22 \pm 0.00$ & $12 \pm 1.32$ & $16 \pm 0.00$ \\
\hline E. coli & - & - & $17.6 \pm 0.66$ & $11 \pm 0.00$ & $15.4 \pm 1.13$ & $9 \pm 0.00$ \\
\hline Serratia marcescens & $2 \pm 0.00$ & - & $19.5 \pm 1.76$ & $8 \pm 0.00$ & $17.5 \pm 1.38$ & $6 \pm 0.00$ \\
\hline Pseudomonas aeruginosa & - & - & $13.2 \pm 1.87$ & $12 \pm 0.00$ & $13.44 \pm 1.12$ & $12 \pm 0.00$ \\
\hline
\end{tabular}

Various possible methods of treat for Ag include interaction with (i) different thiol groups of enzymes or peptides; (ii) chloride ions; or (iii) DNA, among others. Observed manifestations include decrease DNA replication efficiency, membrane structural change, and the formation of granules by silver and sulphur [28,46-50].

MIC values for E. coli and S. aureus recorded in this study are higher than those observed by Vertelov et al. (1 $\mu \mathrm{g} / \mathrm{mL}$ for E. coli and $5 \mu \mathrm{g} / \mathrm{mL}$ for S. aureus) [51] and lower than those reported by Chudasama et al. (100 $\mu \mathrm{g} / \mathrm{mL}$ for E. coli and $350 \mu \mathrm{g} / \mathrm{mL}$ for S. aureus) [28]. This phenomenon can be explained by strain to strain variation, as is the stabilization of AgNPs. The MIC values which detected in this study are much lower than those recorded by commercially prepared antibacterial products. Improved antibacterial activity of AgNPs is due in part to their uniform shape, small size and partial size distribution. An alternate explanation involves high colloidal stability, through which NPs are easily absorbed into the bacterial wall particle-bacterial interaction is enhanced [28,44,50,52].

These results indicate that biosynthesized AgNPs exhibit greater antibacterial activity in comparison to $\mathrm{AgNO}_{3}$ and chemically synthesized AgNPs. Enhanced antibacterial activity may be attributable to the small size and concentration of the biosynthesized NPs and/or the presence of bioactive compound capping. Small AgNPs may be easily diffused or may penetrate a bacterial cell membrane and inhibit its growth by interfering in the natural metabolism processes. Furthermore, plant-based AgNPs production depends on their metabolism. Metabolites, for instance, phenolics, organic acids, and quinones, as well as ascorbates or catechol (as redox system) play important roles in AgNPs formation [25].

Major chemical constituents of aqueous D. moldavica leaf extracts were identified, and included terpenoids, steroids, flavonoids, alkaloids, lignins, phenols, coumarins, and cyanogenic glucosides. These findings indicate that the slightly increased antimicrobial activity of green synthesized AgNPs may be a result of organic content found in D. moldavica seed extracts. A comparison of antimicrobial activity in D. moldavica seed extracts with green synthesized AgNPs (Table 1) confirmed that secondary metabolites play a significant role in capping Ag ions; therefore, despite the low content of synthesized AgNPs as indicated by EDX, secondary metabolites tend to exhibit activity levels that produce effective antibacterial properties at very low concentrations.

\section{Conclusions}

Resulting in considerably improved AgNPs production due to its ability to control nanostructures, the suggested plant-mediated synthesis method is an inexpensive approach capable of producing AgNPs at room temperature. Through a process of characterizing nanoparticles, the present study demonstrated that AgNPs are capable of rendering high antibacterial results, and therefore show great potential for the preparation of antibacterial drugs. Results confirmed that the D. moldavica is a higher quality eco-friendly and safe source for AgNPs synthesis than conventional chemical or physical methods, and its utility invites further investigation. 
Acknowledgments: This research was supported by Damghan branch of Islamic Azad University, Damghan, Iran.

Author Contributions: Z.A. performed the experiments and analyzed the data; N.K. conceived and designed the experiment, wrote the protocol, and wrote the first draft of the manuscript; H.A. designed a part of experiments; A.F. performed and analyzed a part of manuscript.

Conflicts of Interest: The authors declare no conflict of interest.

\section{References}

1. Lin, C.A.; Yang, T.Y.; Lee, C.H.; Huang, S.H.; Sperling, R.A.; Zanella, M.; Li, J.K.; Shen, J.L.; Wang, H.H.; Yeh, H.I.; et al. Synthesis, characterization, and bioconjugation of fluorescent gold nanoclusters toward biological labeling applications. ACS Nano 2009, 3, 395-401. [CrossRef] [PubMed]

2. Rao, C.N.R.; Kulkarni, G.U.; Thomas, P.J.; Edwards, P.P. Metal nanoparticles and their assemblies. Chem. Soc. Rev. 2000, 29, 27-35. [CrossRef]

3. Yallappa, S.; Manjanna, J.; Dhananjaya, B.L. Phytosynthesis of stable Au, Ag and Au-Ag alloy nanoparticles using J. Sambac leaves extract, and their enhanced antimicrobial activity in presence of organic antimicrobials. Spectrochim. Acta Part A Mol. Biomol. Spectrosc. 2015, 137, 236-243. [CrossRef] [PubMed]

4. Iram, F.; Iqbal, M.S.; Athar, M.M.; Saeed, M.Z.; Yasmeen, A.; Ahmad, R. Glucoxylan-mediated green synthesis of gold and silver nanoparticles and their phyto-toxicity study. Carbohydr. Polym. 2014, 104, 29-33. [CrossRef] [PubMed]

5. Vijayaraghavan, K.; Nalini, S.; Prakash, N.U.; Madhankumar, D. One step green synthesis of silvernano/microparticles using extracts of Trachyspermum ammi and Papaver somniferum. Colloid Surf. B Biointerfaces 2012, 94, 114-117. [CrossRef] [PubMed]

6. Nazeruddina, G.M.; Prasada, N.R.; Prasadd, S.R.; Shaikha, Y.I.; Waghmareb, S.R.; Adhyapak, P. Coriandrum sativum seed extract assisted in situ green synthesis of silver nanoparticle and its anti-microbial activity. Ind. Crops Prod. 2010, 60, 212-216.

7. Joerger, R.; Klaus, T.; Granqvist, C.G. Biologically produced silvercarbon composite materials for optically functional thin-film coatings. Adv. Mater. 2000, 12, 407-409. [CrossRef]

8. Fayaz, A.M.; Balaji, K.; Girilal, M.; Yadav, R.; Kalaichelvan, P.T.; Venketesan, R. Biogenic synthesis of silver nanoparticles and their synergistic effect with antibiotics: A study against gram-positive and gram-negative bacteria. Nanomedicine: Nanotechnology. Biol. Med. 2010, 6, 103-109. [CrossRef] [PubMed]

9. Kowshik, M.; Ashtaputre, S.; Kharrazi, S.; Vogel, W.; Urban, J.; Kulkarni, S.K.; Paknikar, K.M. Extracellular synthesis of silver nanoparticles by a silver-tolerant yeast strain MKY3. Nanotechnology 2003, 14, 95. [CrossRef]

10. Otari, S.V.; Patil, R.M.; Ghosh, S.J.; Pawar, S.H. Green phytosynthesis of silver nanoparticles using aqueous extract of Manilkara zapota (L.) seeds and its inhibitory action against Candida species. Mater. Lett. 2014, 116, 367-369. [CrossRef]

11. Sadeghi, B.; Gholamhoseinpoor, F. A study on the stability and green synthesis of silver nanoparticles using Ziziphora tenuior (Zt) extract at room temperature. Spectrochim. Acta Part A Mol. Biomol. Spectrosc. 2015, 134, 310-315. [CrossRef] [PubMed]

12. Iravani, S. Green synthesis of metal nanoparticles using plants. Green Chem. 2011, 13, 2638-2650. [CrossRef]

13. Jayaseelana, C.; Ramkumarb, R.; Rahumana, A.A.; Perumalb, P. Green synthesis of gold nanoparticles using seed aqueous extract of Abelmoschus esculentus and its antifungal activity. Ind. Crops Prod. 2013, 45, 423-429. [CrossRef]

14. Sastry, M.; Ahmad, A.; Khan, M.I.; Kumar, R. Biosynthesis of metal nanoparticles using fungi and actinomycete. Curr. Sci. 2003, 85, 162-170.

15. Jones, S.A.; Bowler, P.G.; Walker, M.; Parsons, D. Controlling wound bioburden with a novel silver-containing Hydrofiber dressing. Wound Repair Regen. 2004, 12, 288-294. [CrossRef] [PubMed]

16. Jagtap, U.B.; Bapat, V.A. Green synthesis of silver nanoparticles using Artocarpus heterophyllus Lam. Seed extract and its antibacterial activity. Ind. Crops Prod. 2013, 46, 132-137. [CrossRef]

17. Bar, H.; Bhui, D.K.; Sahoo, G.P.; Sarkar, P.; Pyne, S.; Misra, A. Green synthesis of silver nanoparticles using seed extract of Jatrophacurcas. Colloid Surface A 2009, 348, 212-216. [CrossRef]

18. Kora, A.; Arunachalam, J. Biosynthesis of silver nanoparticles by the seed extract of Strychnospotatorum: A natural phytocoagulant. IET Nanobiotechnol. 2013, 7, 83-89. [CrossRef] [PubMed] 
19. Showmya, J.; Harini, K.; Pradeepa, M.; Thiyagarajan, M.; Manikandan, R.; Venkatachalam, P.; Geetha, N. Rapid green synthesis of silver nanoparticles using seed extract of Foenculum vulgare and screening of its antibacterial activity. Plant Cell Biotechnol. Mol. Biol. 2012, 13, 31-38.

20. Mohammadinejad, R.; Pourseyedi, S.; Baghizadeh, A.; Ranjbar, S.; Mansoori, G.A. Synthesis of silver nanoparticles using Silybum marianum seed extract. Int. J. Nanosci. Nanotechnol. 2013, 9, 221-226.

21. Venkateswarlu, S.; Kumar, B.N.; Prasad, C.H.; Venkateswarlu, P.; Jyothi, N.V.V. Bioinspired green synthesis of $\mathrm{Fe}_{3} \mathrm{O}_{4}$ spherical magnetic nanoparticles using Syzygium cumini seed extract. Phys. B Condens. Matter 2014, 449, 67-71. [CrossRef]

22. Dastmalchi, K.; Damien-Dorman, H.J.; Laakso, I.; Hiltunen, R. Chemical composition and antioxidative activity of Molavian balm (Dracocephalum moldavica L.) extracts. LWT Food Sci. Technol. 2007, 40, 1655-1663. [CrossRef]

23. Hebbalalu, D.; Lalley, J.; Nadagouda, M.; Varma, R. Greener techniques for the synthesis of silver nanoparticles using plant extracts, enzymes, bacteria, biodegradable polymers, and microwaves. ACS Sustain. Chem. Eng. 2013, 1, 703-712. [CrossRef]

24. Park, Y.; Hong, Y.N.; Weyers, A.Y.; Kim, S.; Linhardt, R.J. Polysaccharides and phytochemicals: A natural reservoir for the green synthesis of gold and silver nanoparticles. IET Nanobiotechnol. 2011, 5, 69-78. [CrossRef] [PubMed]

25. Manivasagan, P.; Kim, S.K. Biosynthesis of nanoparticles using marine algae: A review. In Marine Algae Extracts: Processes, Products, and Applications; Kim, S.K., Chojnacka, K., Eds.; Wiley-VCH: Weinheim, Germany, 2015.

26. Jayaseelan, C.; Rahuman, A.A.; Rajakumar, G.; Santhoshkumar, T.; Kirthi, A.V.; Marimuthu, V.; Bagavan, A.; Kamaraj, C.; Zahir, A.A.; Elango, G.; et al. Efficacy of plant-mediated synthesized silver nanoparticles against hematophagous parasites. Parasitol. Res. 2013, 111, 921-933. [CrossRef] [PubMed]

27. Saha, B.; Bhattacharya, J.; Mukherjee, M.; Ghosh, A.K.; Santra, C.R.; Dasgupta, A.K.; Karmakar, P. In vitro structural and functional evaluation of gold nanoparticles conjugated antibiotics. Nanoscale Res. Lett. 2007, 2, 614. [CrossRef]

28. Chudasama, B.; Vala, A.K.; Andhariya, N.; Mehta, R.V.; Upadhyay, R.V. Highly bacterial resistant silver nanoparticles: Synthesis and antibacterial activities. J. Nanoparticle Res. 2010, 12, 1677-1685. [CrossRef]

29. Gopinath, V.; MubarakAli, D.; Priyadarshini, S.; Priyadharsshini, N.M.; Thajuddin, N.; Velusamy, P. Biosynthesis of silver nanoparticles from Tribulus terrestris and its antimicrobial activity: A novel biological approach. Colloids Surf. B Biointerfaces 2012, 96, 69-74. [CrossRef] [PubMed]

30. Shin, Y.; Bae, I.T.; Arey, B.W.; Exarhos, G.J. Facile stabilization of gold-silver alloy nanoparticles on cellulose nanocrystal. J. Phys. Chem. C 2008, 112, 4844-4848. [CrossRef]

31. Basavaraja, S.; Balaji, S.; Lagashetty, D.A.; Rajasab, A.H.; Venkataraman, A. Extracellular biosynthesis of silver nanoparticles using the fungus Fusarium semitectum. Mater. Res. Bull. 2008, 43, 1164-1170. [CrossRef]

32. Raja, K.; Saravanakumar, A.; Vijayakumar, R. Efficient synthesis of silver nanoparticles from Prosopis juliflora leaf extract and its antimicrobial activity using sewage. Spectrochim. Acta Part A 2012, 97, 490-494. [CrossRef] [PubMed]

33. Ankamwar, B.; Damle, C.; Ahmad, A.; Sastry, M.; Nanosci, J. Biosynthesis of gold and silver nanoparticles using Emblica officinalis fruit extract, their phase transfer and transmetallation in an organic solution. J. Nanosci. Nanotechnol. 2005, 5, 1665-1671. [CrossRef] [PubMed]

34. El-Nour, K.M.A.; Eftaiha, A.A.; Al-Warthanb, A.; Ammar, R.A. Synthesis and applications of silver nanoparticles. Arab. J. Chem. 2010, 3, 135-140. [CrossRef]

35. Shankar, S.S.; Ahmad, A.; Pasricha, R.; Sastry, M. Bioreduction of chloroaurate ions by geranium leaves and its endophytic fungus yields gold nanoparticles of different shapes. J. Mater. Chem. 2003, 13, 1822-1826. [CrossRef]

36. Yallappa, S.; Manjanna, J. Biological evaluation of silver nanoparticles obtained from T. arjuna bark extract as both reducing and capping agent. J. Clust. Sci. 2014, 25, 1449-1462. [CrossRef]

37. Jiang, X.; Sun, D.; Zhang, G.; He, N.; Liu, H.; Huang, J.; Odoom-Wubah, T.; Li, Q. Investigation of active biomolecules involved in the nucleation and growth of gold nanoparticles by Artocarpus heterophyllus Lam leaf extract. J. Nanoparticle Res. 2013, 15, 1741-1751. [CrossRef]

38. Song, J.Y.; Kim, B.S. Rapid biological synthesis of silver nanoparticles using plant leaf extracts. Bioprocess Biosyst. Eng. 2009, 32, 79-84. [CrossRef] [PubMed] 
39. Raghunandan, D.; Ravishankar, B.; Sharanbasava, G.; Mahesh, D.B.; Harsoor, V.; Yalagatti, M.S.; Bhagawanraju, M.; Venkataraman, A. Anti-cancer studies of noble metal nanoparticles synthesized using different plant extracts. Cancer Nanotechnol. 2011, 2, 57-65. [CrossRef] [PubMed]

40. Leu, J.G.; Chen, S.A.; Chen, H.M.; Wu, W.M.; Hung, C.F.; Yao, Y.D.; Tu, C.S.; Liang, Y.J. The effects of gold nanoparticles in wound healing with antioxidant epigallocatechin gallate and $\alpha$-lipoic acid. Nanotechnol. Biol. Med. 2012, 87, 8767-8775. [CrossRef] [PubMed]

41. Deshpande, L.M.; Chopade, B.A. Plasmid mediated silver resistance in Acinetobacter baumannii. Biometals 1994, 7, 749-756. [CrossRef]

42. Van den Wildenberg, W. Roadmap Report on Nanoparticles; W\&W. Espana sl.: Barcelona, Spain, 2005.

43. Annamalai, J.; Nallamuthu, T. Green synthesis of silver nanoparticles: Characterization and determination of antibacterial potency. Appl. Nanosci. 2016, 6, 259-265. [CrossRef] [PubMed]

44. Ingle, A.; Gade, A.; Pierrat, S.; Sonnichsen, C.; Rai, M. Mycosynthesis of silver nanoparticles using the fungus Fusarium acuminatum and its activity against some human pathogenic bacteria. Curr. Nanosci. 2008, 4, 141-144. [CrossRef]

45. Liu, J.Y.; Sonshine, D.A.; Shervani, S.; Hurt, R.H. Controlled release of biologically active silver from nanosilver surfaces. ACS Nanotechnol. 2010, 4, 6903-6913. [CrossRef] [PubMed]

46. Kim, S.; Choi, J.E.; Choi, J.; Chung, K.H.; Park, K.; Yi, J. Oxidative stress-dependent toxicity of silver nanoparticles in human hepatoma cells. Toxicol. Vitro 2009, 23, 1076-1084. [CrossRef] [PubMed]

47. Shrivastava, S.; Bera, T.; Roy, A.; Singh, G.; Ramachandrarao, P.; Dash, D. Characterization of enhanced antibacterial effects of novel silver nanoparticles. ACS Nanotechnol. 2007, 3, 1357-1364. [CrossRef]

48. Yu, S.J.; Yin, Y.G.; Liu, J.F. Silver nanoparticles in the environment. Environ. Sci. 2013, 15, 78-92. [CrossRef]

49. Feng, Q.L.; Wu, J.; Chen, G.Q.; Cui, F.Z.; Kim, T.N.; Kim, J.O. A mechanistic study of the antibacterial effect of silver ions on Escherichia coli and Staphylococcus aureus. J. Biomed. Mater. Res. 2010, 52, 662-668. [CrossRef]

50. Morones, J.R.; Elechiguerra, J.L.; Camacho, A.; Holt, K.; Kouri, J.B.; Ramfrez, J.T.; Yacaman, M.J. The bactericidal effect of silver nanoparticles. Nanotechnology 2005, 16, 2346-2353. [CrossRef] [PubMed]

51. Vertelov, G.K.; Krutyakov, Y.A.; Efremenkova, O.V.; Olenin, A.Y.; Lisichkin, G.V. A versatile synthesis of highly bactericidal Myramistin stabilized silver nanoparticles. Nanotechnology 2008, 19, 355707. [CrossRef] [PubMed]

52. Melaiye, A.; Sun, Z.; Hindi, K.; Milsted, A.; Ely, D.; Reneker, D.H.; Tessier, C.A.; Youngs, W.J. Silver (I) imidazole cyclophane gem-Dio complexes encapsulated by electrospun tecophilic nanofibers: Formation of nanosilver particles and antimicrobial activity. J. Am. Chem. Soc. 2005, 127, 2285-2291. [CrossRef] [PubMed] 